\title{
Saison•kalender Gemüse
}

Im Sommer gibt es viel verschiedenes Gemüse.

Aber auch im Winter gibt es mehr Auswahl, als man denkt.

Viele Sorten kann man auch das ganze Jahr kaufen. Im Frühling gibt es am wenigsten frisches Gemüse. Die Lager sind leer und frisches Gemüse muss erst noch wachsen.

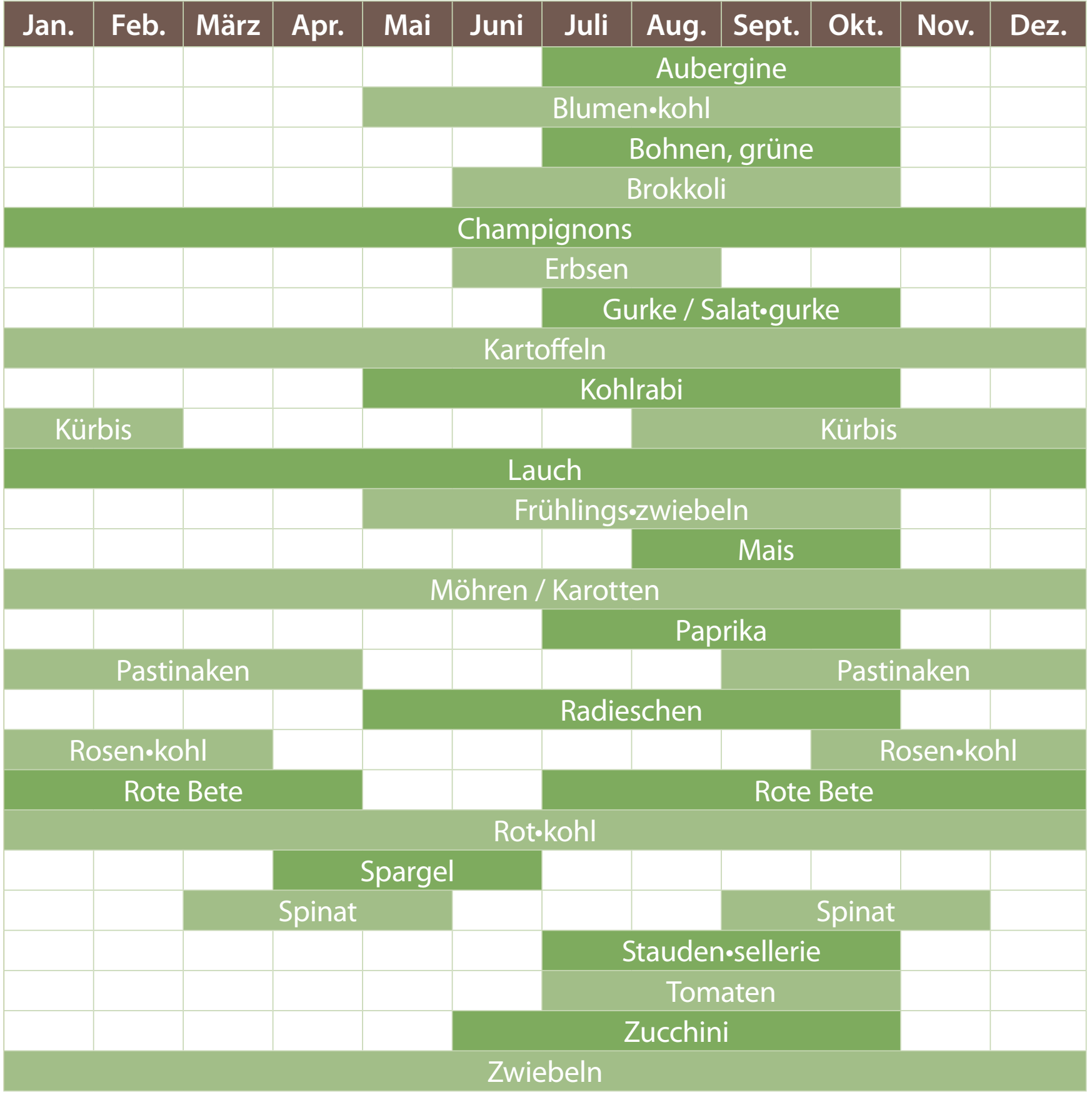

